\title{
Problem solving process and creative thinking of students in ecosystem issue
}

\author{
Delinta Herlina Santi a,1,*, Baskoro Adi Prayitno b,2, M. Muzzazinah a,3 \\ a Department of Biology Education, Postgraduate, Universitas Sebelas Maret, Jl. Ir. Sutami 36A Kentingan, Jebres, Surakarta \\ Central Java 57126, Indonesia \\ ${ }^{b}$ Department of Biology Education, Faculty of Teacher Training and Education, Universitas Sebelas Maret, Ir. Sutami street 36A \\ Kentingan, Jebres, Surakarta, Central Java 57126, Indonesia \\ ${ }^{1}$ delinta.dhs@gmail.com * ; ${ }^{2}$ baskoro_ap@fkp.uns.ac.id ; ${ }^{3}$ yayin_pbio@fkip.uns.ac.id \\ ${ }^{*}$ Corresponding author
}

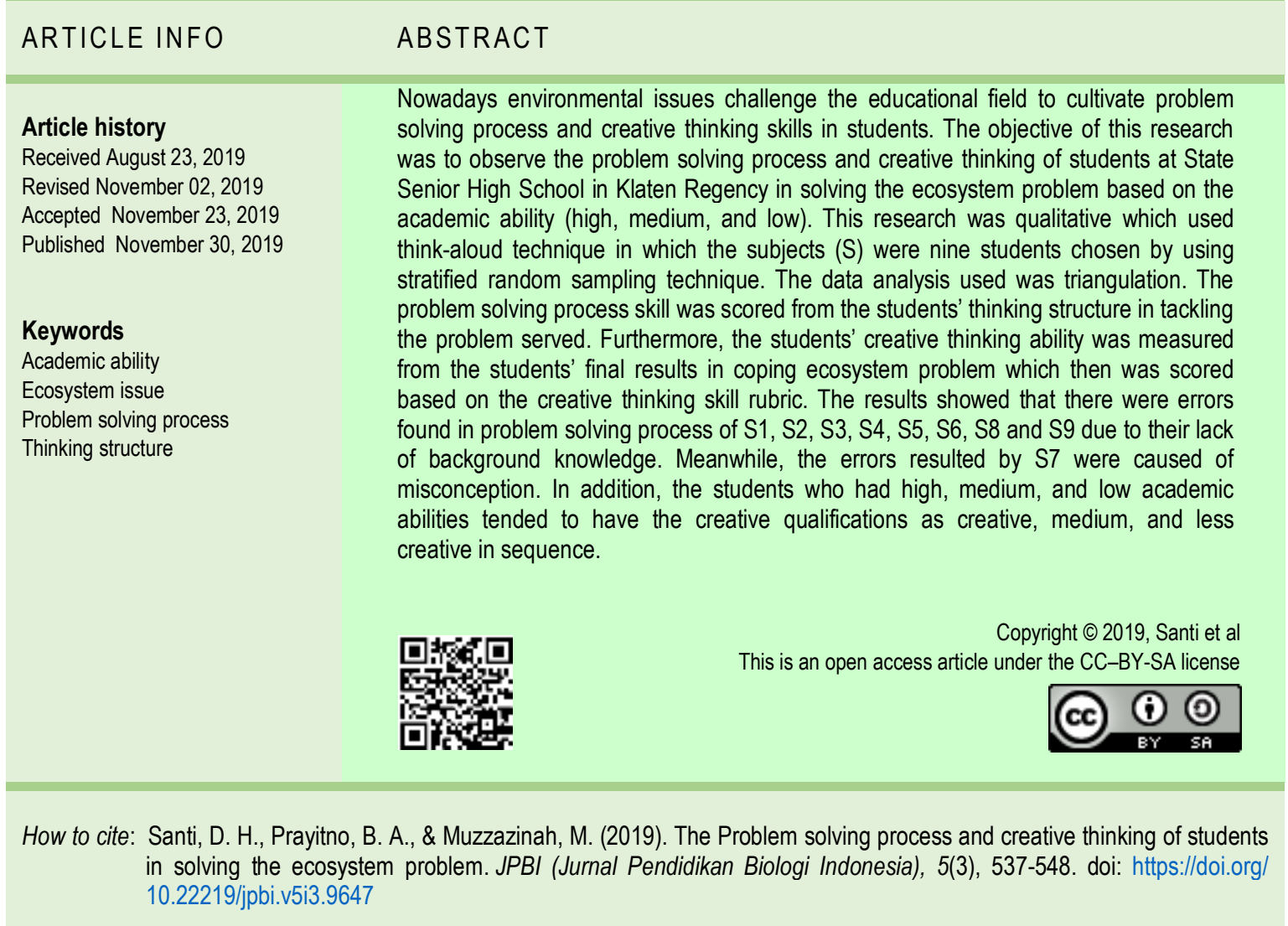

\section{INTRODUCTION}

Biology learning emphasizes students to be able to apply technology in digital era literacy, creative, and criticism in their thinking so that they have excellent interpersonal and social skills. Challenges faced by the $21^{\text {st }}$ century education is the quality of education and individual which underline an innovative thinking (Kellner, 2000). Students' creative and innovative thinking should enable them to analyze the problems faced as well as determine a new ideas as the solution (Cropley, Kaufman, \& Cropley, 2011; Reiter-palmon, 2011). Students' thinking ability can be deliberately known by assessing their capability in handling problems (Heong 
et al., 2012). Meanwhile, by possessing creative thinking, students are enabled to comprehend and master the concepts given in a good way. As the consequences, their abilities in reasoning, critical thinking, decision making, creative thinking will be established. Santrock (2009) stated that there must be an effort to transform the information which is started from analyzing and creating a conclusion in thinking activity.

Creative thinking is an essential basic in empowering students' thinking ability (Songkram, 2015). Every student has different creative thinking to generate several new ideas (Petre, 2018) from any different perspectives as they have different quality of thinking and solving problems (Nadeem, Shamim-ur-rasool, \& Haq, 2012). Solving problem implementation in learning activity is one of the effective methods to increase students' creativity (Silver, 1997). It also enables students to assess information and by conducting fully consideration as well as find the undergirding cause of the problems arose (Aka, 2010). Creative thinking skill increases students creativity in tackling problems (Çetinkaya, 2014). This learning technique trains students' creative thinking in accomplishing or solving problem based on the information collected and the students' thinking pattern developed in elaborating the ideas proposed. The more real condition descripted the more serious student efforts to solve the problem. Thus, a real environmental problem served to be solved by students is important to be done.

The environmental problem case suit to be studied by students is the blooming of water hyacinths plants (Eichhornia crassipes) in Rawa Jombor. Rawa Jombor is an artificial ecosystem located in Jimbung, Krakitan, Bayat, Klaten, Central Java, Indonesia. This reservoir functions as irrigation canal, tourism (floating shop) destination, and karamba (fish net cage). However, an unbalance ecosystem has occurred as the abundance of Eichhornia crassipes which covered up to $40 \%$ of the aquatic area. Eichhornia crassipes has been known as the worst water weeds in the world as the eutrophication caused gives adverse effects to the environment (Zhang, Zhang, \& Barrett, 2010; Ingwani, Gumbo, \& Gondo, 2010). It has risen the death of red tilapia fish (Oreochromis niloticus) as high as $25 \%$. Not only environmental problem, the weeds also causes social and economy issues as their growth are stimulated by the flow of rich-nutrients water and the other water treatment waste (Villamagna \& Murphy, 2010).

Through creative thinking, the students are able to analyze the problem served so that they find out the process of problem solving and bring out the new idea in coping the problem. This creative thinking skill is measured using several indicators: 1) fluency, 2) flexibility, 3) elaboration, 4) originality (Torrance, 1972). This research aimed at revealing the process of problem solving and creative thinking from the students of State Senior High School at Klaten Regency, Central Java-Indonesia in solving the ecosystem problem based on their academic ability (high, medium, and low). The research contribution is the description of the problem solving process and creative thinking of high school students at different levels of academic ability on ecosystem issues. The results of the study will challenge teachers to work on strategies for developing students' problem solving abilities and creative thinking skills based on their level of academic ability.

\section{METHOD}

The sample of research were chosen from the $11^{\text {th }}$ graders of State Senior High School in Klaten Regency, Central Java, Indonesia which consisted of 19 schools. The schools were chosen and graded based on the National Examination (NE) score achieved by students in each school. After grading process, there were six schools chosen which comprised of two schools from upper, middle, and lower levels. Furthermore, the consideration of choosing the six schools was the analysis of students' National Examination (UN) scores to determine their academic ability. The selected students then were interviewed to get the information about their verbal skills. As many as nine students with good verbal skills were chosen as the research samples which comprised of high, medium, and low levels of academic abilities. The students were labelled as $S_{1}$ (First Subject), $S_{2}$ (Second Subject), $S_{3}$ (Third Subject), $S_{4}$ (Fourth Subject), $S_{5}$ (Fifth Subject), $S_{6}$ (Sixth Subject), $S_{7}$ (Seventh Subject), $S_{8}$ (Eight Subject), $S_{9}$ (Ninth Subject).

\section{Instrument and procedures}

The instrument used in this research was test which was arranged based on creative thinking aspects in terms of fluency, flexibility, elaboration, and originality. Furthermore, it was validated by learning and evaluation experts. The instrument made achieved 26 for material aspect, 76 for questions presentation, 28 for scoring rubric, and 28 for indicators suitability from learning validator. Meanwhile, the evaluation expert gave scores: 26 for material aspect, 83 for question presentation, 29 for scoring rubric, and 28 for the 
indicators suitability. The percentage calculation was then done to ensure the instrument eligibility. As the score gained was 84\%, it was then converted to the criteria from Sudjana (2009) as served in Table 1.

Table 1. The interpretation criteria of validator expert score

\begin{tabular}{ccc}
\hline Interval & Criteria & Convertion \\
\hline $86 \% \leq \mathrm{N}<100 \%$ & Very Good & $\mathrm{A}$ \\
$72 \% \leq \mathrm{N}<85 \%$ & Good & $\mathrm{B}$ \\
$58 \% \leq \mathrm{N}<71 \%$ & Enough & $\mathrm{C}$ \\
$44 \% \leq \mathrm{N}<57 \%$ & Poor & $\mathrm{D}$ \\
$\mathrm{N} \leq 44 \%$ & Very Poor & $\mathrm{E}$ \\
\hline
\end{tabular}

The interpretation result of the score gained, it can be seen that the instrument made was categorized as "good" criteria. The instrument was also used to know the error of problem solving constructed by students as well as to determine students' creative thinking based on their academic ability.

The collecting data procedure was comprised of five steps: (1) asking questions to the students about the ecosystem case, (2) asking the students to answer the questions given, (3) discussing the problem, (4) asking students to revise their work results, and (5) asking students to speak loudly about what they were thinking about (Think out Louds) and recording it.

\section{Data analysis}

The data analysis technique used was triangulation of the data gained. The data were collected from different sources, including writing results, using think aloud method. The triangulation results of creative thinking were then analyzed using developmental level qualifications of creative thinking. Siswono (2011) divided four level qualifications of creative thinking (served in Table 2).

Table 2. Level qualifications of creative thinking

\begin{tabular}{ccl}
\hline No & Qualifications of creative thinking & \multicolumn{1}{c}{ Criteria } \\
\hline 1 & Very creative & $\begin{array}{l}\text { Able to analyze, develop, and expand a problem with one or more alternative } \\
\text { answers flexibly so that a new idea can be produced. } \\
\text { Able to analyze, develop, and expand a problem with one or more alternative } \\
\text { answers but less flexibility so that having less capability to produce new idea. }\end{array}$ \\
3 & Creative & $\begin{array}{l}\text { Able to analyze a problem but not fluent and inflexible so that having less capability } \\
\text { to produce new idea. } \\
\text { Able to analyze a problem but not fluently and inflexibility so that have no capability to } \\
\text { produce new idea. }\end{array}$ \\
5 & Luite creative & Not able to make alternative answers and have no capability to solve the problem. \\
\hline
\end{tabular}

Furthermore, the problem solving process produced by students were then cross-checked with students' thinking structure. The expected thinking structures of student to solve ecosystem problem are served in Table 3.

Table 3. The descriptions of problem structure code

\begin{tabular}{cl}
\hline Code & \\
\hline MA & The problem which causes the growth of water hyacinth plant (Eichhornia crassipes) covers up to $40 \%$ of Rawa Jombor \\
A1 & The problem was caused by the using of chemical fertilizer \\
A2 & The problem was caused by the using of pesticide \\
A3 & The problem was caused by the detergent waste disposal to the river flow which was flowing to the swamp \\
X & The impact which was caused from the growth of water hyacinth plant (Eichhornia crassipes) which could not be \\
& controlled through the balancing of ecosystem in di Rawa Jombor \\
B1 & From abiotic factor \\
C1 & Causing swamp silting \\
C2 & Make the water become cloudy \\
C3 & Make the water volume decrease due to evaporation process \\
B2 & From biotic factor \\
C4 & Make the fish lack of oxygen $\left(\mathrm{O}_{2}\right)$ \\
C5 & The level of oxygen $\left(\mathrm{O}_{2}\right)$ in the water decreases as it is used for transpiration process of water hyacinth plant (Eichhornia \\
& crassipes) \\
C6 & causing swamp eutrophication \\
B3 & From culture or aesthetics factors \\
C7 & Causing a slum area in the swamp and its surrounding \\
\hline
\end{tabular}




\begin{tabular}{|c|c|}
\hline Code & Description \\
\hline $\mathrm{Y}$ & $\begin{array}{l}\text { The appropriate solution in solving the uncontrolled growth of water hyacinth plant (Eichhornia crassipes) through the } \\
\text { ecosystem balancing of Rawa Jombor }\end{array}$ \\
\hline D1 & $\begin{array}{l}\text { Take away the water hyacinth plant (Eichhornia crassipes) from the swamp to get the benefits for making high economy } \\
\text { value products such as bags, slippers, biogas, animal feed, etc. }\end{array}$ \\
\hline D2 & Decrease the using of chemical fertilizer and pesticide \\
\hline D3 & Do not throw away the detergent waste into the swamp \\
\hline D4 & Spread out grass carp (Ctenopharyngodon idella Val.) \\
\hline D5 & $\begin{array}{l}\text { Use the water hyacinth plant (Eichhornia crassipes) on the edge of the swamp as green belt and filter for the water which } \\
\text { enters the swamp }\end{array}$ \\
\hline D6 & $\begin{array}{l}\text { Make a pool as water storage for each river inlet to swamp to reduce the concentration of nitrogen and phosphorus before } \\
\text { entering the swamp }\end{array}$ \\
\hline S & Finish \\
\hline
\end{tabular}

\section{RESULTS AND DISCUSSION}

The samples tested to find out the process of problem solving and creative thinking were 9 students. The categorization of 9 samples based on their academic ability. The process of problem solving and creative thinking in Rawa Jombor case could be categoryzed as follows.

\section{The process of problem solving and creative thinking from high academic ability student}

The process of problem solving and creative thinking from the first subject $\left(S_{1}\right)$ in solving ecosystem problem are served in Figure 1.

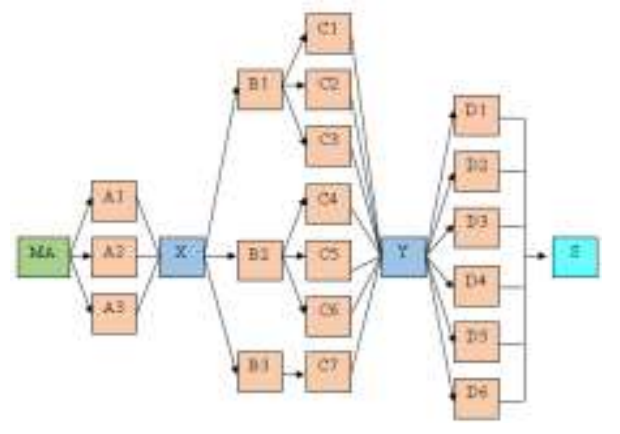

(a)

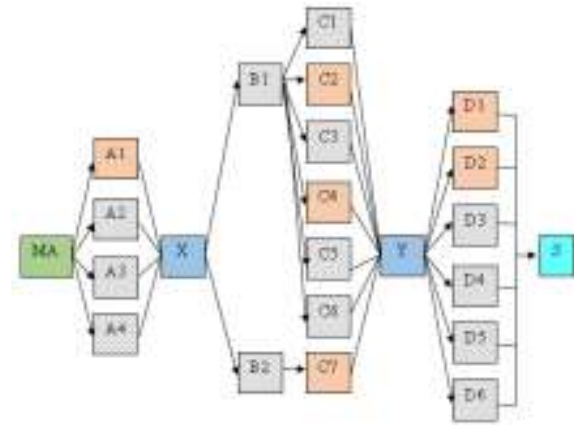

(b)

Descriptions:

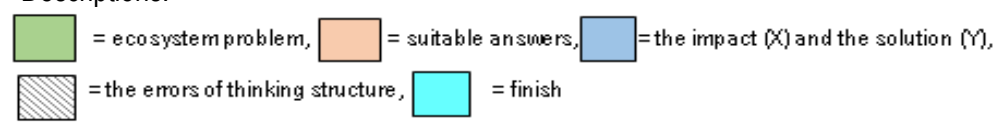

Figure 1. Problem structure (a) and thinking structure in solving the problem (b) of $S_{1}$

Figure 1 showed that thinking structure of $S_{1}$ in solving ecosystem problem contained mistakes in in term of analyzing the reason, impacts, and solution. Figure 1 showed that the $S_{1}$ thought that the undergirding reason of the issue arose was the characteristic of water hyacinth plant (Eichhornia crassipes) that lived in the swamp which grew more fertile as the fertilizer accumulated in the swamp flowed from farm land. The student also assumed that the problem arose disturbed the ecosystem in Rawa Jombor, meanwhile, thus, the solving problem offered was taking away the water hyacinth plant from the swamp and decreased the use of fertilizer in farm land as it is easily dissolved into swamp water. This, in turn, diminished the nutrition for the water hyacinth plant. The mistake done by S1 appeared in the solving problem offered. It can be seen that the student was lack of background knowledge. Yet, Kim and Kim (2018) as well as Niezgoda (2011) stated that the environmental knowledge determines person's behavior towards the environment.

Meanwhile, the $S_{1}$ 's creative thinking skill was analyzed using triangulation in terms of fluency, flexibility, elaboration, and originality. The fluency aspect of $\mathrm{S} 1$ was showed that she/he has the ability in producing various ideas to analyze the problem faced, furthermore, the flexibility of $S_{1}$ implied that she/he own the ability in applying approaches to analyze the problem faced. In addition, the elaboration aspect of S1 was good as she/he has the ability in developing idea as well as giving solution to deal with the problems come which was 
called as originality. Even though for some students, being a creative is difficult (Heong et al., 2012), yet, it can be habituated by certain training. To go further, the results of triangulation process were analyzed based on the qualification levels of creative thinking (served in Table 2). Hence, the $S_{1}$ was recognized as creative qualification.

The process of problem solving and creative thinking produced by the second subject $\left(\mathrm{S}_{2}\right)$ in dealing with ecosystem problem is served in Figure 2. The process of problem solving done by $S_{2}$ in solving the ecosystem problem was correctly structured. It can be seen from the thinking structure performed in analyzing the possible solution (Figure 2). The solution offered by $S_{2}$ was taking away the water hyacinth plant (Eichhornia crassipes) from the swamp and decreasing the use of fertilizer from farm land which is easily dissolved into swamp water, therefore, it would not nourished the plant. The mistake done by $S_{2}$ appeared in the solving problem proposed. The student had low ability in analyzing the undergirding reason and impact of the problem arose as she/he lacked of knowledge.

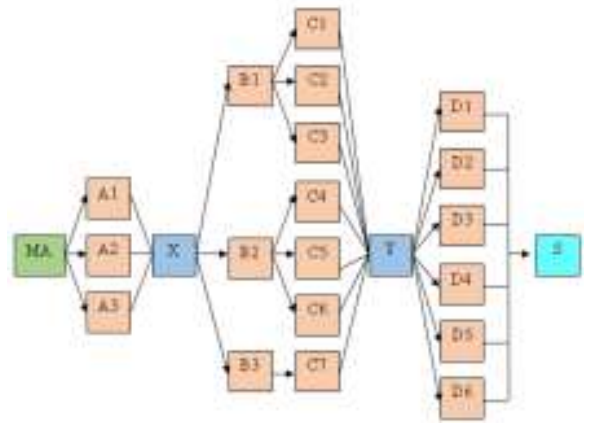

(a)

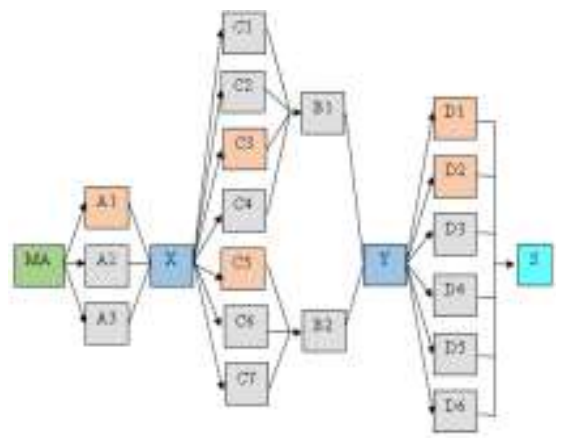

(b)

Figure 2. Problem structure (a) and thinking structure of $S_{2}$ in solving the problem (b)

The results of $S_{2}$ creative thinking were then analyzed using triangulation in terms of fluency, flexibility, elaboration, and its originality aspect. The triangulation results implied that the fluency aspect was achieved successfully by $S_{2}$ which means that the ability in producing various ideas to analyze the problem faced was good. Furthermore, the flexibility was also enacted by $S_{2}$, in the other words, $S_{2}$ has the ability in applying approaches to analyze the problem she/he faced. In addition, based on the elaboration aspect, the $S_{2}$ was able to develop an idea. Based on the originality aspect, $S_{2}$ also possessed the ability in giving solution for the problems came. As the triangulation gained, the level of qualification and creative thinking possessed by $S_{2}$ was determined based on the criteria (Table 2). Hence, the $S_{2}$ was categorized as creative student.

The process of problem solving and creative thinking of $S_{3}$ in dealing with ecosystem issue is served in Figure 3.

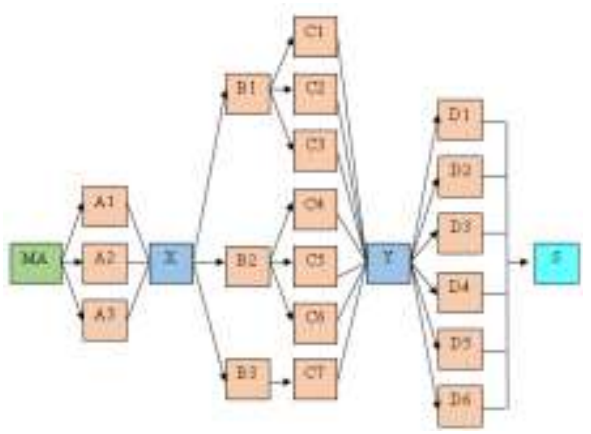

(a)

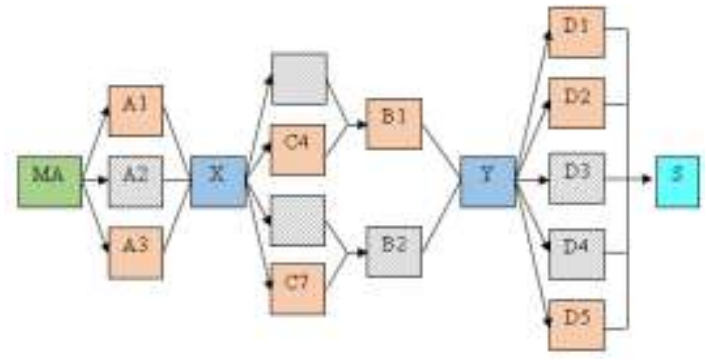

(b)

Figure 3. Problem structure (a) and thinking structures of $S_{3}$ in solving the problem (b)

Figure 3 showed that thinking structure possessed by $S_{3}$ in solving ecosystem problem. It can be seen that $\mathrm{S}_{3}$ assumed that the problem was caused by the appropriate condition provided by the swamp in supporting the growth of water hyacinth plant (Eichhornia crassipes) as the great amount of fertilizer, from farm land, 
dissolved in swamp water. $S_{3}$ also thought that the problem effected the ecosystem balance in Rawa Jombor. The solution proposed by $S_{3}$ to solve the prolem was by taking away the water hyacinth plant (Eichhornia crassipes) from the swamp and diminishing the use of fertilizer which easily dissolved into the swamp water. So that the plant would not be nourished. The mistake appeared in the solving problem offered by $S_{3}$. She/he could not analyze the problem correctly as her/his low level of knowledge. Meanwhile, the $\mathrm{S}_{3}$ 's qualification level of creative thinking, which was determined based on Table 2, was categorized as creative.

\section{The process of problem solving and creative thinking from medium academic ability students}

The process of problem solving and creative thinking produced by the fourth subject $\left(S_{4}\right)$ in solving ecosystem problem is served in Figure $4 . S_{4}$ concluded that the reason of the problem occurred was the water swamp conditions. The waste dissolved in it and the lower water level as the effect of dry season, as well as hot temperature have led to the ecosystem problem (Figure 4). The impact followed the conditions was the disturbance of ecosystem balance and swamp silting. Thus, S4 proposed to take away the water hyacinth plant (Eichhornia crassipes) and the garbage thrown into the swamp. The mistake of $S_{4}$ was found in the solving problem she/he proposed. This because $S_{4}$ lack of knowledge as also appeared clearly when she/he did the think-loud process. $S_{4}$ could not described clearly his/her own reason, moreover, she/he only repeated the previous answers to deal with the questions given. It can be seen that knowledge is essential to provide basic information before student decide what they must do to solve the problem faced in term of constructing the procedure they are going to make. Griffin and Care (2015) said that procedure and methodologies, thinking and strategies are the required components which must be clear to deal with the $21 \mathrm{st}$-century challenges.

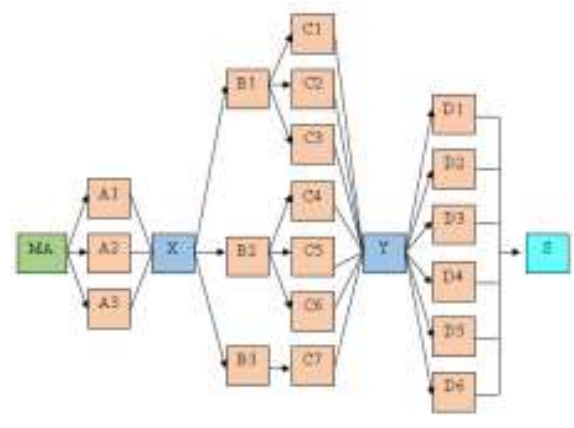

(a)

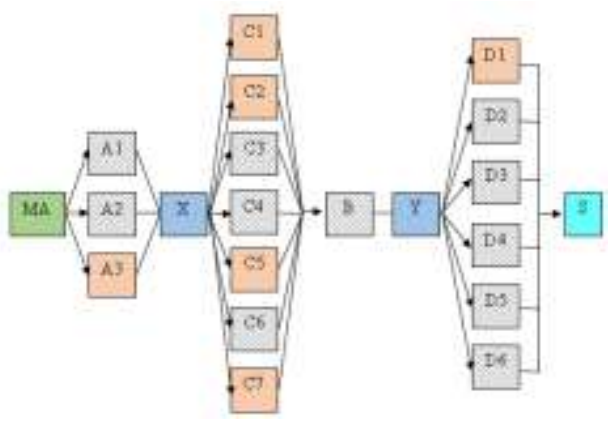

(b)

Figure 4. Problem structure (a) and thinking structure of $S_{4}$ in solving the problem (b)

The triangulation results of $S_{4}$ creative thinking were: 1) $S_{4}$ has less ability in producing various ideas in analyzing the problem, which means that the fluency aspect was not well accommodated by $\left.S_{4} ; 2\right) S_{4}$ could only apply an approach in analyzing the problem, in other words, the flexibility aspect was not well implemented by $S_{4}$; 3 ) based in the elaboration aspect, $S_{4}$ could develop the idea in general way; 4) $S_{4}$ has low ability in producing new ideas. This means that $S_{4}$ needs more stimulations of senses and sensory (Heong et al., 2012), so that he/she gets use to with new situations which stimulate his/her new ideas. Therefore, the qualification level of creative thinking enacted by $S_{4}$ was fair (enough).

The process of problem solving and creative thinking generated by the fifth subject $\left(S_{5}\right)$ in solving ecosystem problem is served in Figure 5. Based on Figure 5, it is known that $S_{5}$ assumed that the ecosystem issue arose in Rawa Jombor swamp was caused by the characteristics of water hyacinth plant (Eichhornia crassipes) morphology and the waste flowed to the area. These conditions have led to the disturbance of the ecosystem in in Rawa Jombor. By considering the cause of the problem, the solution proposed by $S_{5}$ was by taking away the water hyacinth plant from the swamp. The mistake found in the solution proposed by $S_{5}$ as she/he has no adequate knowledge to solve the problem. This fact was clearly appeared as $S_{5}$ could not clearly answer the questions given in think-loud process. Meanwhile, the results of triangulation showed that $\mathrm{S}_{5}$ has less ability in generating various ideas, she/he only applied an approach to solve the problem, moreover, he/she developed idea in general way as the solution, but was less able to produce new idea. Thus, S5's creativity was categorized as "enough" level. 


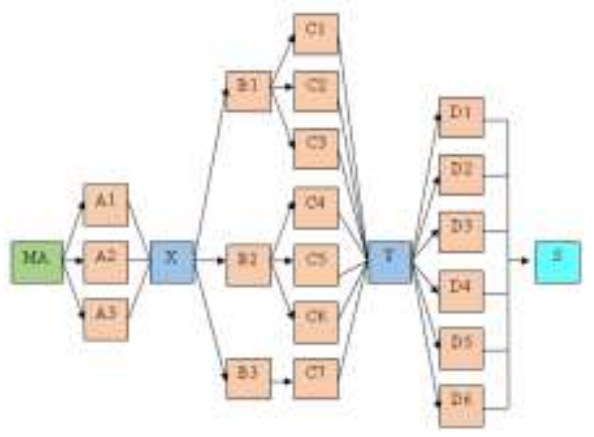

(a)

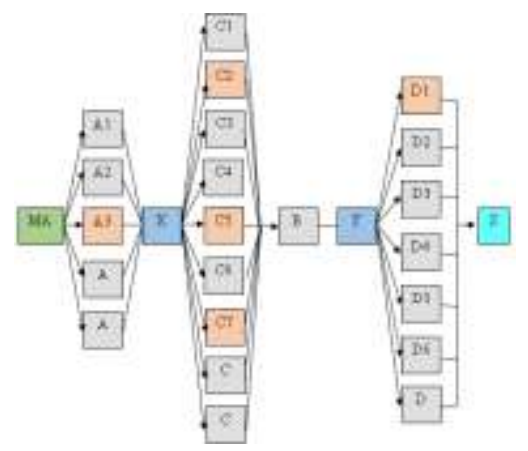

(b)

Figure 5. Problem structure (a) and thinking structure of $S_{5}$ in solving the problem (b)

The process of problem solving and creative thinking resulted by the sixth subject $\left(\mathrm{S}_{6}\right)$ in solving ecosystem problem is served in Figure 6.

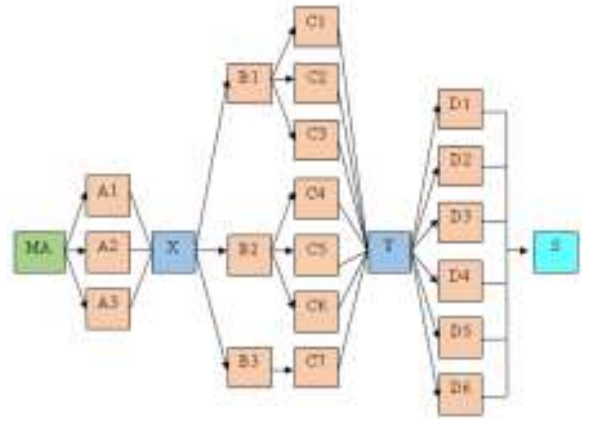

(a)

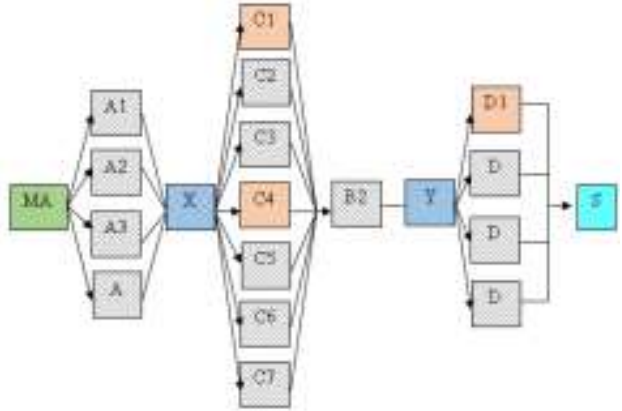

(b)

Figure 6. Problem structure (a) and thinking structure of $S_{6}$ in solving the problem (b)

$\mathrm{S}_{6}$ assumed that the undergirding reason of the problem was the characteristic of water hyacinth plant (Eichhornia crassipes) and its fast reproduction process (Figure 6). The impact emerged from the conditions was the ecosystem disturbance in the swamp as bad as swamp silting. Therefore, the solution proposed by $\mathrm{S}_{6}$ was clean the water hyacinth plant from the swamp. $S_{6}$ has made the same mistake as the two previous students i.e. incorrect solving problem proposed as the less knowledge possessed. Similarly, the fault was clearly seen in the think-aloud process, as $S_{6}$ described that the cause of the problem was only the morphology and physiology of the water hyacinth plant (Eichhornia crassipes).

By conducting triangulation, the S's creative thinking was fair (enough) based on the four aspects analyzed. The fluency and flexibility aspects of $S_{6}$ were not satisfactory as she/he has low ability in producing various ideas to enunciate the problem and only an approach in analyzing the problem. Similarly, the elaboration and originality aspects were also fair as the student only develop the idea in general way and no new idea generated.

\section{The process of problem solving and creative thinking from low academic ability students}

The process of problem solving and creative thinking offered by the seventh subject $\left(S_{7}\right)$ in solving ecosystem problem is served in Figure 7. Based on Figure 7, it can be obviously seen that the cause of the ecosystem issue was the fluctuation of the swamp water levels. The impact of the condition was the ecosystem unbalance of Rawa Jombor. In addition, the solution offered was clean the water hyacinth plant as well as the garbages from the swamp. The misconception was found as the student offered the solving problem. $S_{7}$ thought that the water hyacinth plants in the swamp were cultured and maintained by local people to sell. She/he also assumed that the plants were treated using fertilizers such as several pesticides.

The triangulation results showed that the fluency and flexibility of $S_{7}$ were unsatisfactory. She/he was not able to produce various ideas and only applied an approach to analyze the problem. Meanwhile, the elaboration and originality were fair as the student could develop the idea in general way, yet he/she has low 
ability in producing new idea. Thus, the level qualification of creative thinking possessed by $S_{7}$ was "less creative".

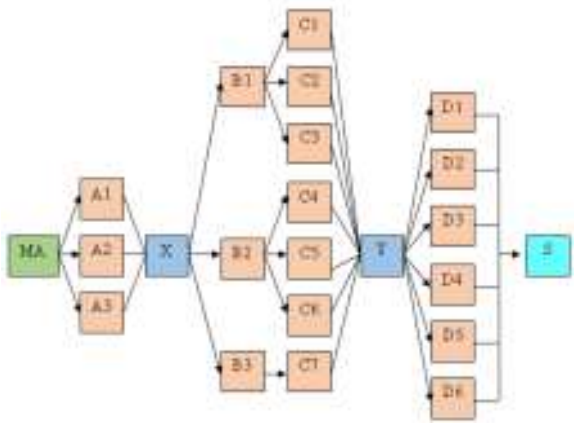

(a)

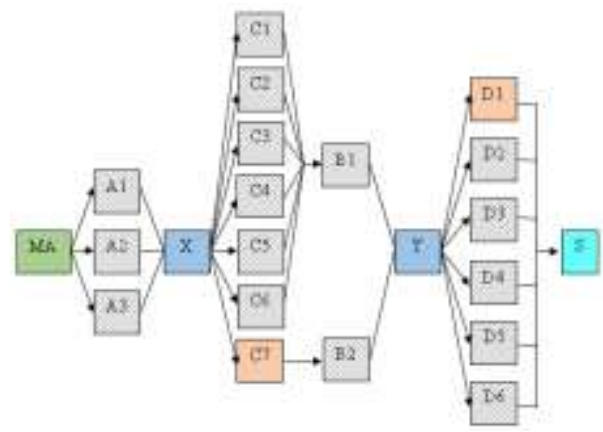

(b)

Figure 7. Problem structure (a) and thinking structure of $S_{7}$ in solving the problem (b)

The process of problem solving and creative thinking generated by the eighth subject $\left(\mathrm{S}_{8}\right)$ in solving ecosystem problem is served in Figure 8. Based on Figure 8, it can be seen that $\mathrm{S}_{8}$ assumed that the problem arose was caused by the swamp water condition. The impact emerged was the disturbance of swamp ecosystem. Thus, the solution offered by $S_{8}$ was clean up the water hyacinth plant from the swamp. The mistake made by $S_{8}$ was caused by the low level of knowledge possessed by $S_{8}$. It can be proven from the think-aloud activity done. $S_{8}$ explained that the problem could be solved by reducing the number of water hyacinth plant through spraying pesticides on plant leaves, the $S_{8}$ even mentioned specific pesticides to kill the plant.

The results of triangulation process of $S_{8}$ creative thinking in solving the problem implied that the qualification level of $S_{8}$ creative thinking was "les creative". $S_{8}$ could not produce various ideas to analyze the problem, he/she only apply an approach to analyze the problem and develop the idea in general way. Similarly, $S_{8}$ has low ability in producing new idea.

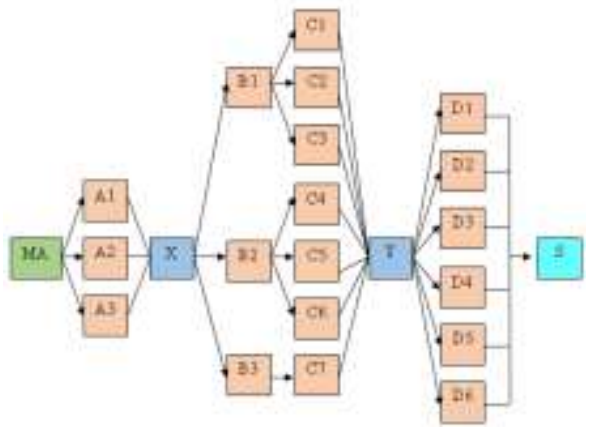

(a)

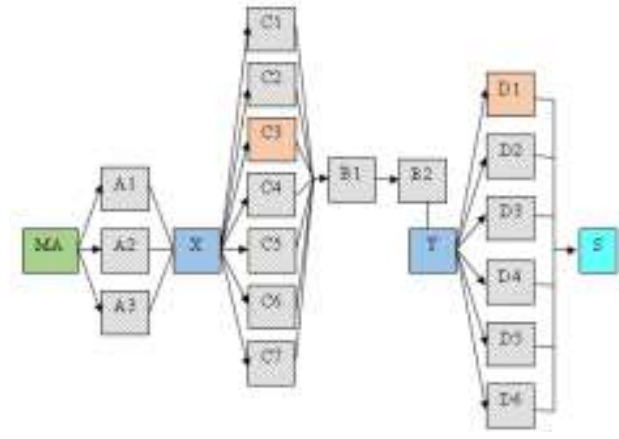

(b)

Figure 8. Problem structure (a) and thinking structure of $S_{8}$ in solving the problem (b)

The process of problem solving and creative thinking generated by the ninth subject $\left(\mathrm{S}_{9}\right)$ in solving ecosystem problem is served in Figure 9 . It can be clearly seen that $S_{9}$ analyzed that the cause of the ecosystem problem was the water condition, so that the impact emerged was the unbalance ecosystem of Rawa Jombor. Thus, the solving offered was cleaning the swamp from the water hyacinth plant. The mistake made by $S_{9}$ was because she/he has inadequate of knowledge. This was also obvious when $S_{9}$ could not answer correctly the questions given in think-aloud activity related to the problem.

The triangulation process of $S_{9}$ creative thinking results implied that the qualification level of $S_{9}$ was "less creative". S9 could not produce various ideas in analyzing the problem given, she/he also only apply an approach in analyzing the problem, develop an idea in general way, and could not produce new idea in solving the problem. This is an evidence that without clear method, students could not achieve their success (Griffin \& Care, 2015). 


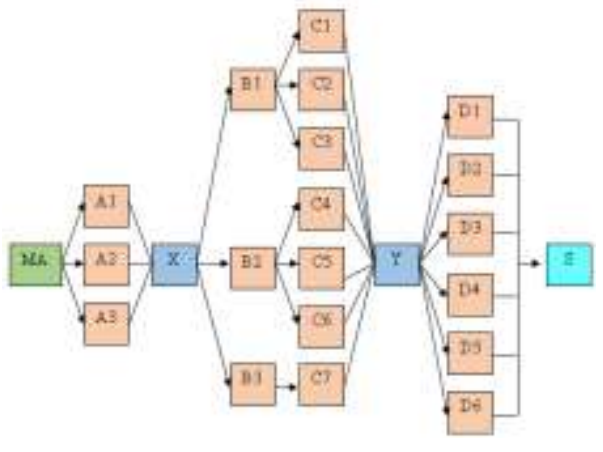

(a)

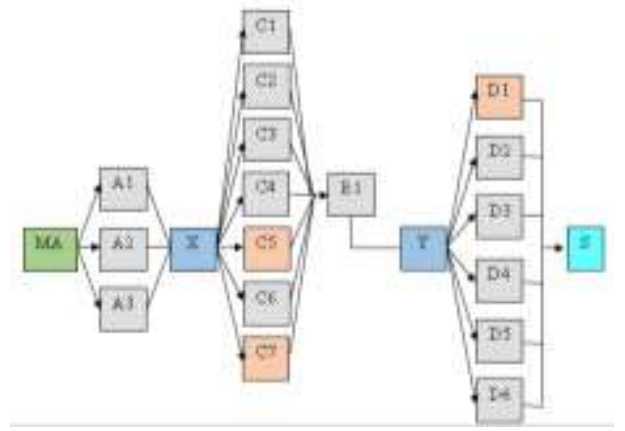

(b)

Figure 9. Problem structure (a) and thinking structure of $S_{9}$ in solving the problem (b)

Generally, the results of this research showed that the three groups of students with different academic levels (high, medium, and low) performed similar in term of creative thinking. This finding is in line with the previous report revealed by Santi, Prayitno, and Muzzazinah (2018) which showed that creative thinking skills possess by students with high and low academic abilities were in the same low level due to the lack of knowledge. This finding is also supported with the evidences that the student thinking structure provided the same errors in solving the ecosystem issue given. The solving problem process made by students with the high academic ability $\left(S_{1}, S_{2}, S_{3}\right)$ had a mistake in arguing that the undergirding reason of the problem was the characteristic of water hyacinth plant which was more fertile as there were chemical fertilizer dissolved in water swamp. Yet, the steps taken to cope with the problem were taking the water hyacinth plant from the swamp and diminishing the fertilizer which possibly flowed to the swamp water.

In addition of the study results, students with high, medium, and low academic ability did an error in their structural thinking in solving the ecosystem problem. This can be seen as the students were not able to analyze the problem correctly. They could not notice that the water hyacinth plants would be uncontrolled in Rawa Jombor and being disturbance for the environment. This was caused by the lack of background knowledge and misconception. Shea, Mckenna and Thomson (2019) stated that an error of students' structural thinking is caused by the lack of reading interest owned by student which leads them to the condition of lack of knowledge.

Meanwhile, the mistake also found in the process generated by the medium academic ability students $\left(S_{4}\right.$, $\left.S_{5}, S_{6}\right)$. The low level of environmental knowledge was the reason of the mistake found. In one hand, $S_{4}$ and S5 thought that the problem emerged was caused by the domestic waste which run into the swamp water, on the other hand $\mathrm{S}_{6}$ assumed that the problem arose was caused by the morphology of water hyacinth plant and no correlation with the water swamp condition. Yet, the interesting thing was, albeit that the reason assumed were various, yet the solution proposed to solve the ecosystem problem was the same among the three students (i.e. clean the water hyacinth plant from the water swamp).

The group student with low academic ability did the error in solving the ecosystem problem given. S7 did the mistake as the consequence of her/his misconception, meanwhile, $S_{8}$ and $S_{9}$ did their mistake as their low level of knowledge. Misconception is an error knowledge of students which is not properly describe the concept (Hamza \& Wickman, 2007; Taylor \& Kowalski, 2004). Misconception possessed by $\mathrm{S}_{7}$ was his/her assumption that the water hyacinth plant is not a problem as the plants are deliberately maintained by local people, through the treatment of fertilizer, which, in turn, will give them financial benefit after selling the harvested plants. In addition, the thinking structures of $S_{8}$ and $S_{9}$ led them to the assumption that the swamp conditions were suitable for the water hyacinth growth, even though, they coud not explain the description of the conditions required by the plant to grow.

It was expected that the students could analyze properly the detail of undergirding reason of the uncontrollable growth of water hyacinth plant from various perspectives. Moreover, the students were also expected to have the ability in analyzing properly about the impact which possible arose as they observe the abiotic and biotic factors surrounding the swamp area. Thus, the solution offered would be related to the height growth of water hyacinth plant. This means that the students were demanded to give the relevant solutions to each problem existed as well as providing new ideas as the alternatives which possibly used to deal with the problem. Pukdeewut, Chantarasombat, and Satapornwong (2013) said that students attained knowledge, skill, and attitude towards creative learning activity management. Thus, there must be a great 
design to habituate the students to get what they need to be creative person. One of the design is the use of proper learning model (Husamah, Fatmawati, \& Setyawan, 2018).

However, there also interesting findings revealed in this study. It was found that the groups of students have different ability in producing new ideas. The higher the level of academic ability, the better the ability in initiating new ideas. This showed that creative thinking needs to be trained and practiced in students' daily life. Hence, solving certain problems can measure students' creative thinking (Çetinkaya, 2014; Pizzingrilli, Valenti, Cerioli, \& Antonietti, 2015).

The students with creative qualification can be observed from the way they coping the problem. They can develop and expand their ideas in several ways of thinking, yet they were unable to analyze some approaches which limited them to generate the more various new ideas. Meanwhile, the students with medium academic ability was qualified as quite creative based in the way they solved the problem. Even though they could describe the problem, but they could not apply some approches, thus, they could not produce new idea. In addition, the students with low academic ability was qualified as less creative as their performance in solving the problem. They could only answer the questions about ecosystem problem based on their shallow knowledge due to their unability in analyzing approaches which led them to have no new idea condition.

\section{CONCLUSION}

The results of research showed that the ecosystem case in Rawa Jombor could reveal the students' ability in problem solving process and creative thinking. Students with high academic ability tend to perform their creative thinking ability with creative qualification. Students with medium academic ability tend to have creative thinking ability with quite creative qualification. Students with low academic ability tend to have creative thinking ability with less creative qualification. Yet, the students with high, medium, and low academic abilities were unable to optimize their knowledge so that it is needed to be practiced with more serious effort to deal with problems faced, especially in the field of biology in ecosystem materials. Lack of knowledge is the cause of the low creative thinking owned by students.

\section{ACKNOWLEDGMENT}

The authors' acknowledgments are conveyed for several parties who were involved in this research, namely, the all Biology teachers in the $11^{\text {th }}$ grade and all of the principals of State High Schools in Klaten Regency, Central Java who had given permission to conduct this research.

\section{REFERENCES}

Aka, E. G. (2010). Effect of problem solving method on science process skills and academic achievement. Journal of Turkish Science Education, 7(4), 13-25. Retrieved from https://www.tused.org/index.php/ tused/article/view/533/459

Azizah, N. R., Masykuri, M., \& Prayitno, B. A. (2018). Scaffolding as an effort for thinking process optimization on heredity Scaffolding as an effort for thinking process optimization on heredity. Journal of Physics: Coference Series. doi: https://doi.org/10.1088/1742-6596/1006/1/01/2017.

Çetinkaya, Ç. (2014). The effect of gifted students ' creative problem solving program on creative thinking. Procedia-Social and Behavioral Sciences, 116(1974), 3722-3726. doi: https://doi.org/10.1016/j.sbspro. 2014.01.830.

Cropley, D. H., Kaufman, J. C., \& Cropley, A. J. (2011). Measuring creativity for innovation management. Journal of Technology Management and Innovation, 6(3). Retrieved from https://www.jotmi.org/index. php/GT/article/view/art204/636

Griffin, P., \& Care, E. (2015). Assessment and teaching of 21st century skills. London: Springer Dordrecht Heidelberg. doi: http://doi.org/10.1007/978-94-017-9395-7

Guilford, J. (1975). Varieties of creative giftedness, their measurement and development. Gifted Child Quarterly, 19(2), 107-121. doi: https://doi.org/10.1177/001698627501900216.

Hamza, K. M., \& Wickman, P. (2007). Describing and analyzing learning in action: An empirical study of the importance of misconceptions in learning science. Science Education, 92, 141-164. doi: https://doi.org/ 


\subsection{2/sce.20233}

Heong, Y. M., Yunos, J. M., Othman, W., Hassan, R., Tee, T. K., \& Mohamad, M. M. (2012). The needs analysis of learning higher order thinking skills for generating ideas. Procedia-Social and Behavioral Sciences, (59), 197-203.doi: http://doi.org/10.1016/j.sbspro.2012.09.265

Husamah, H., Fatmawati, D., \& Setyawan, D. (2018). OIDDE learning model: Improving higher order thinking skills of biology teacher candidates. International Journal of Instruction, 11(2), 249-264. doi: http://doi. org/10.12973/iji.2018.11217a

Ingwani, E., Gumbo, T., \& Gondo, T. (2010). The general information about the impact of water hyacinth on Aba Samuel Dam, Addis Ababa, Ethiopia: Implications for ecohydrologists. Journal Ecohydrology Hydrobiology, 10(2-4), 341-345. doi: https://doi.org/10.2478/v10104-011-0014-7.

Kellner, D. (2000). New Technologies / New Literacies: Reconstructing education for the new millennium New Technologies / New Literacies : reconstructing education for the new millennium. Teaching Education, 6210(June). doi: https://doi.org/10.1080/713698975.

Kim, M., \& Kim, J. (2018). Influence of environmental knowledge on affect, nature affiliation and proenvironmental behaviors among tourists. MDPI, (10), 1-16. doi: http://doi.org/10.3390/su10093109

Lee, K.S., Hwang, D., Seo, J.J. (2003). A development of the test for mathematical creative problem solving ability. Journal of The Korea Society of Mathematical Education, 7(3), 163-189. Retrieved from http:// www.koreascience.or.kr/article/JAKO200311921974337.page

Nadeem, M. A., Shamim-ur-rasool, S., \& Haq, R. (2012). A comparison of creative thinking abilities of high and low achievers secondary school students. International Interdisciplinary Journal of Education, 1(1), 3-8. Retrieved from http://iijoe.org/v1/IJE_04_v1_i1_2012.pdf

Niezgoda, A. (2011). The role of environmental knowledge, attitudes and initiatives in the development of a tourism product. Tourism, 21, 33-39. doi: http://doi.org/10.2478/v10106-011-0004-6

Petre, V. (2018). Educating which creativity? Thinking Skills and Creativity, 27, 25-32. doi: https://doi.org/10. 1016/j.tsc.2017.11.006.

Pizzingrilli, P., Valenti, C., Cerioli, L., \& Antonietti, A. (2015). Creative thinking skills from 6 to 17 Years as assessed through the WCR test. Procedia-Social and Behavioral Sciences, 191, 584-590. doi: https:/l doi.org/10.1016/j.sbspro.2015.04.498.

Prayitno, B. A., Suciati, \& Titikusumawati, E. (2018). Enhancing students' higher order thinking skills in science through. Journal of Baltic Science Education, 17(6), 1046-1055. doi: https://doi.org/10.33225/ jbse/18.17.1046.

Pukdeewut, S., Chantarasombat, C., \& Satapornwong, P. (2013). Creative thinking development program for learning activity management of secondary school teachers. International Education Studies, 6(12). doi: http://doi.org/10.5539/ies.v6n12p82

Reiter-palmon, R. (2011). Introduction to special issue: The psychology of creativity and innovation in the workplace. Psychology of Aesthetics Creativity, and the Arts, 5(1), 1-2. doi: https://doi.org/10.1037/a001 8586.

Santi, D. H., Prayitno, B. A., \& Muzzazinah, M. (2018). Exploring ecosystem problems: A way to analyze a profile of creative thinking skills in upper and lower academic students in senior high school in Klaten regency. International Coference on Science and Applied Science: AIP Coference Proceedings, 20117, 10-14. doi: https://doi.org/10.1063/1.5054521.

Santrock, J. (2009). Educational psychology. Jakarta: Salemba Humanika. Retrieved from https://epdf.pub/ educational-psychology-5th-edition.html

Shea, C. O., Mckenna, S., \& Thomson, C. (2019). "We throw away our books": Students' reading practices and identities. Linguistics and Education, 49, 1-10. doi: https://doi.org/10.1016/j.linged.2018.11.001.

Silver, E. (1997). Fostering creativity through instruction rich in mathematical problem solving and problem posing. Journal Mathematic Education, 29(3), 75-80. Retrieved from https://www.emis. de/journals/ZDM Izdm973a3.pdf

Siswono, E. (2011). Level of student's creative thinking in classroom mathematics. Educational Research and Review, 6(7), 548-553. Retrieved from https://academicjournals.org/article/article1379767432_Siswono. pdf.

Songkram, N. (2015). E-learning system in virtual learning environment to develop creative thinking for learners in higher education. Procedia-Social and Behavioral Sciences, 174, 674-679. doi: https://doi.or g/10.1016/j.sbspro.2015.01.600.

Sudjana, N. (2006). Penilaian hasil proses belajar mengajar. Bandung: Remaja Rosdakarya. Retrieved from 
https://opac. perpusnas.go.id/DetailOpac. aspx?id=586982.

Taylor, A. K., \& Kowalski, P. (2004). Naive psychological science: the prevalence, strength, and sources of misconceptions. The Psychological Record, 54, 15-25. Retrieved from https://opensiuc.lib.siu.edu/cgi/ viewcontent.cgi?article=1218\&context=tpr

Torrance, E. P. (1972). Can we teach children to think creatively? Journal of Creative Behavior, 6(2), 114-143. https://doi.org/10.1002/j.2162-6057.1972.tb00923.x

Villamagna, A. ., \& Murphy, B. (2010). Ecological and socio-economic impacts of invasive water hyacinth (Eichhornia crassipes): a review. Freshwater Biology, 55, 282-298. doi: https://doi.org/10.1111/j.13652427.2009.02294.X.

Zhang, Y.-Y., Zhang, D.-Y., \& Barrett, S. (2010). Genetic uniformity characterizes the invasive spread of water hyacinth (Eichhornia crassipes), a clonal aquatic plant. Molecular Biology, 19, 1774-1786. doi: https:/l doi.org/10.1111/j.1365-294X.2010.04609.x. 